\title{
The Effect of Using Commercial Red and Black Iron Oxides as a Concrete Admixtures on its Physiochemical and Mechanical Properties
}

\author{
Essam A. Kishar ${ }^{2}$, Muhammad Y. Alasqalani ${ }^{1}$, Yahya R. Sarraj ${ }^{3}$, Doaa A. Ahmed ${ }^{4}$ \\ ${ }^{1}$ Chemistry Department, Women College, Ain Shams University, Cairo, Egypt. \\ ${ }^{2}$ Scientific research department, Israa University-Gaza, Palestine. \\ ${ }^{3}$ Civil Engineering Department, Islamic University-Gaza, Palestine. \\ ${ }^{4}$ Chemistry Department, Women College, Ain Shams University, Cairo, Egypt.
}

\begin{abstract}
Study discuss the effect of using commercial red and black iron oxides (RIO and BIO) as a concrete admixtures in percentages do not exceeded $2.5 \%$ of each oxide from the amount of cement, this study tested the effect of every portion from each oxide at different ages on the compressive strength as well as the workability represented as a values of slump. We conclude that the optimum portion of RIO is $2.5 \%$, but for BIO is $1 \%$, while the proposed uses of RIO in concrete technology are retarder through slump increment reach to 50\%, coloring material and mineral admixture through Compressive Strength increment (7-365 days) 5.5-12.8\%. On the other hand BIO will propose as, coloring material and mineral admixture through Compressive Strength increment (7-365 days) 22.2-30.8\%. SEM-images are clearly show the formation of Calcium hydroxide phase at 7-days while at 1-year the C-S-H phase is a predominate one, in both cases of RIO and BIO. XRD-pattern is supported the results outcomes through SEM-images.
\end{abstract}

Keywords: RIO, BIO, Compressive strength, SEM, slump

\section{Introduction}

Admixtures are those ingredients in concrete other than Portland cement, water, and aggregates that are added to the mixture immediately before or during mixing. Admixtures can be classified by function as follows:

1) Air-entraining admixtures

2) Water-reducing admixtures

3) Plasticizers

4) Accelerating admixtures

5) Retarding admixtures 6. specialty admixtures: which include corrosion inhibitors, shrinkage control, alkalisilica reactivity inhibitors, and coloring. [1].

Iron oxides classified as coloring admixture, in addition it improve some mechanical properties as out lined in [2], which conclude that, The using of nano $\mathrm{ZrO}_{2}, \mathrm{Fe}_{3} \mathrm{O}_{4}, \mathrm{TiO}_{2}$ and $\mathrm{Al}_{2} \mathrm{O}_{3}$ with constant content will enhance the mechanical properties of fresh and hardened concrete as compressive strength, indirect tensile strength and durability. The same result is adopted in [3], work; it can be used, iron oxide , as pigment with percent less than $4 \%$ in concrete. The iron oxide will enhance some of the mechanical properties of hardened concrete as compressive and flexure strength.

$\mathrm{Fe}_{3} \mathrm{O}_{4}$ is used as a black pigment and is known as C.I pigment black 11 (C.I. No.77499). Iron (III) oxide is also used as a pigment, under names "Pigment Brown 6", "Pigment Brown 7", and "Pigment Red 101"; Iron (II, III) oxid (black iron oxide) is a chemical compound with formula $\mathrm{Fe}_{3} \mathrm{O}_{4}$. It contains both $\mathrm{Fe}^{2+}$ and $\mathrm{Fe}^{3+}$ ions and sometimes formulate as $\mathrm{FeO} \cdot \mathrm{Fe}_{2} \mathrm{O}_{3}$.
In the work of [4], in soil the following behavior of iron oxides is proposed, when surface of iron oxides is covered with $\mathrm{OH}$ ions attached to $\mathrm{Fe}$ (III) atoms; these species are called surface functional groups and contribute substantially to the specific adsorption of various anions as inner sphere complexes. Common sorbates are phosphate, silicate, arsenate and humic compounds, as well as cations such as heavy metals. This adsorption makes the soil mantle act as an efficient sink for these ions and molecules thereby restricting the electrostatic interactions.

\section{Experimental}

\subsection{Materials}

- Portland cement of mark CEM I 52.5N obtained from ElArish cement factory. Its chemical composition is given in Table (1)

Table 1: Chemical composition of the used ordinary Portland cement (OPC)

\begin{tabular}{|c|c|}
\hline Oxide (\%) & OPC \\
\hline $\mathrm{SiO}_{2}$ & 22.12 \\
\hline $\mathrm{Al}_{2} \mathrm{O}_{3}$ & 5.56 \\
\hline $\mathrm{Fe}_{2} \mathrm{O}_{3}$ & $\mathbf{3 . 6 9}$ \\
\hline $\mathrm{CaO}$ & 62.87 \\
\hline $\mathrm{Na}_{2} \mathrm{O}$ & 0.29 \\
\hline $\mathrm{K}_{2} \mathrm{O}$ & 0.11 \\
\hline $\mathrm{Cl}$ & 0.02 \\
\hline $\mathrm{MgO}$ & 2.36 \\
\hline $\mathrm{SO}_{3}$ & 0.91 \\
\hline Free CaO & 0.92 \\
\hline Ignition Loss & $\mathbf{1 . 2 2}$ \\
\hline
\end{tabular}




\section{International Journal of Science and Research (IJSR) \\ ISSN (Online): 2319-7064}

Index Copernicus Value (2013): 6.14 | Impact Factor (2014): 5.611

- Red and black iron oxides:

The main physical and chemical properties is listed in Table (2) according to Fisher Scientific Company for red iron oxide, and Procter Johnson Company for black iron oxide.

Table Error! No text of specified style in document.: Physical and chemical properties of Red and Black iron oxide

\begin{tabular}{|c|c|c|}
\hline Property & Red Iron oxide & Black Iron oxide \\
\hline Molecular formula & $\mathrm{Fe}_{2} \mathrm{O}_{3}$ & $\mathrm{Fe}_{3} \mathrm{O}_{4}$ \\
\hline Appearance & Red Powder & Black Powder \\
\hline Toxicity & Not toxic & Not toxic \\
\hline Solubility in water & Insoluble & Insoluble \\
\hline Normal Size $(\mathrm{nm})$ & $\sim 100$ & $\sim 100$ \\
\hline $\begin{array}{c}\mathrm{pH} \text { in } 5 \% \mathrm{w} / \mathrm{w} \\
\text { concentration }\end{array}$ & Not available & $4-8$ \\
\hline Bulk Density kg/m & 1550 & 1500 \\
\hline
\end{tabular}

\section{- Aggregate:}

Aggregates used in this study achieved specification of ASTM.

\section{- Water:}

Tape water is used for all mixing and curing of concrete.

\subsection{Techniques and Instrumentation}

\subsubsection{Mix Design}

After finishing of all tests for concrete constituent and ensure that all material like water, aggregate, sand and cement are according to ASTM specification, the concrete will design with strength $30 \mathrm{MPa}$ at 28 days age. The job mix will be designed according to Standard Practice for Selecting Proportions for Normal, Heavyweight, and Mass Concrete [5]. The design criteria that used in the current study is as:

1)Compressive strength: The most strength of normal concrete for general use is $30 \mathrm{MPa}$ for cubic strength and $25 \mathrm{MPa}$ for cylinder strength so the mix will be design for that strength.

2)Slump: The most slump of normal concrete for general use is between 25 to $100 \mathrm{~mm}$ and the mix is designed for slump around 75 to $100 \mathrm{~mm}$.

3)Nominal maximum aggregate size: The nominal maximum aggregate size in the job mix is $25 \mathrm{~mm}$.

4) Water cement ratio: The water cement ratio in the job mix is 0.569 .

5)The final average weight for job mix: The final average weight for the job mix is list in Table (3).

Table 31: The final average weight for the job mix

\begin{tabular}{|c|c|c|}
\hline Material & Weight $(\mathrm{kg})$ & Volume $\left(\mathrm{m}^{3}\right)$ \\
\hline Entrapped air & 0 & 0.0150 \\
\hline Water & 182 & 0.1650 \\
\hline Cement & 320 & 0.1016 \\
\hline Coarse aggregate & 1161 & 0.4519 \\
\hline Fine aggregate & 687 & 0.2665 \\
\hline Total & 2350 & 1.000 \\
\hline
\end{tabular}

\subsubsection{Preparation of Concrete Specimen}

\subsubsection{Mixing Procedure}

The concrete will mix according to Standard Method of Making and Curing Test Specimens in the Laboratory [6].

\subsubsection{Curing of hardened concrete:}

After 20-40 hour, the hardened concrete will be removed from the molds very carefully to prevent any defect in the samples. After that, the samples will be placed in curing water tank at temperature $21-25^{\circ} \mathrm{C}$ until the period of testing.

\subsubsection{Testing program}

The main aim of this research is to study the effect of red and black iron oxides on the mechanical properties of fresh and hardened concrete and find the ability to obtain high strength concrete using components as limestone aggregate, sand, cement and, red and black iron oxides which valuable in local market. To study the effects of red and black iron oxides on the mechanical property of fresh and hardened concrete should be flow many testes on fresh and hardened concrete, these tests are explained as following.

\section{Fresh concrete test and sampling:}

1) Slump Test according to [7]:

2) Sampling of fresh concrete in several molds according to [6]:

\section{Testing of Hardened Concrete}

After completing the curing process for hardened concrete, many tests should be made to study physiochemical and mechanical properties of hardened concrete as below.

1)Compressive strength According to [8] and [9].

2)Stopping of hydration: This is performed after doing the compressive strength test by taking about $10 \mathrm{~g}$ of the crushed hardened pastes and putting into a beaker containing $100 \mathrm{ml}$ of acetone/ethyl alcohol (1:1 by volume) to stop the hydration process. The mixture is stirred for 0.5 $\mathrm{hr}$. The residue is filtered off, ished with ethanol and dried at $50^{\circ} \mathrm{C}$ for about $24 \mathrm{hrs}$. The dried samples are then stored in a desiccator for the following physico-chemical analysis.

3)X-Ray Diffraction analysis (XRD): XRD patterns of the samples are recorded by using a Philips X Pert MPD diffractometer using copper target with nickel filter under working conditions of 40 kilovolts and 20 milliampers.

4)Scanning Electron Microscopic (SEM) measurements: The morphology and microstructure of the dried hydrated samples are studied using JEOL JEM -1200 EXII electron microscope. The specimens are coated with a thin film of gold under a vacuum evaporator with cathode rays then analyzed.

\section{Results and Discussion}

\subsection{Black iron oxide}

The following table will outline the results of slump as well as compressive strength of concrete using black iron oxides (BIO): 


\section{International Journal of Science and Research (IJSR) \\ ISSN (Online): 2319-7064 \\ Index Copernicus Value (2013): 6.14 | Impact Factor (2014): 5.611}

Table 4: Slump and compressive strength of concrete using BIO

\begin{tabular}{|c|c|c|c|c|c|c|}
\hline Portion & Slump & \multicolumn{5}{|c|}{ Compressive strength $\left(\mathbf{k g} / \mathbf{c m}^{2}\right)$} \\
\cline { 3 - 7 }$\left(\mathrm{M} / \mathrm{C}^{*} / \mathrm{)}\right)$ & $(\mathrm{cm})$ & 7-days & 28-days & 96-days & 6-mon. & 1-year \\
\hline 0 & 8 & 360 & 375 & 385 & 395 & 390 \\
\hline 0.5 & 7 & 440 & 450 & 450 & 470 & 500 \\
\hline 1 & 8.5 & 440 & 460 & 470 & 480 & 510 \\
\hline 1.5 & 9.5 & 410 & 420 & 400 & 450 & 455 \\
\hline 2 & 12 & 390 & 405 & 430 & 470 & 480 \\
\hline 2.5 & 13 & 380 & 400 & 420 & 420 & 430 \\
\hline
\end{tabular}

$* \mathrm{M} / \mathrm{C}=$ amount of iron oxide in grams (M) / amount of cement in grams (C)

BIO produce approximately linear behavior of slump increasing, this fashion illustrated in Fig. 1, the maximum increasing of concrete slump, which is $13 \mathrm{~cm}$, produced by $2.5 \%$ portion. Detectable increasing in the concrete compressive strength using BIO as admixture, this increasing comes to be in maximum value at $1 \%$ portion at one year age, Fig. 2, outline the pattern of concrete compressive strength using BIO.

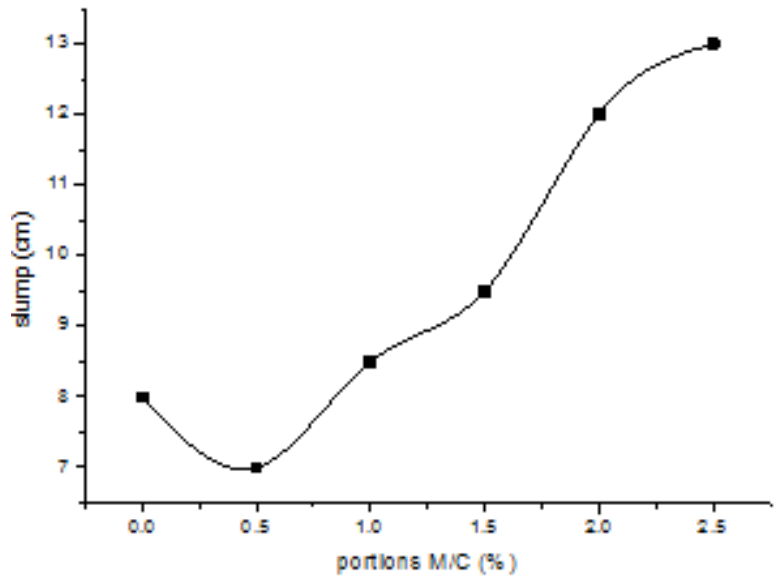

Figure 1: Effect of $\mathrm{BIO}$ on the concrete slump

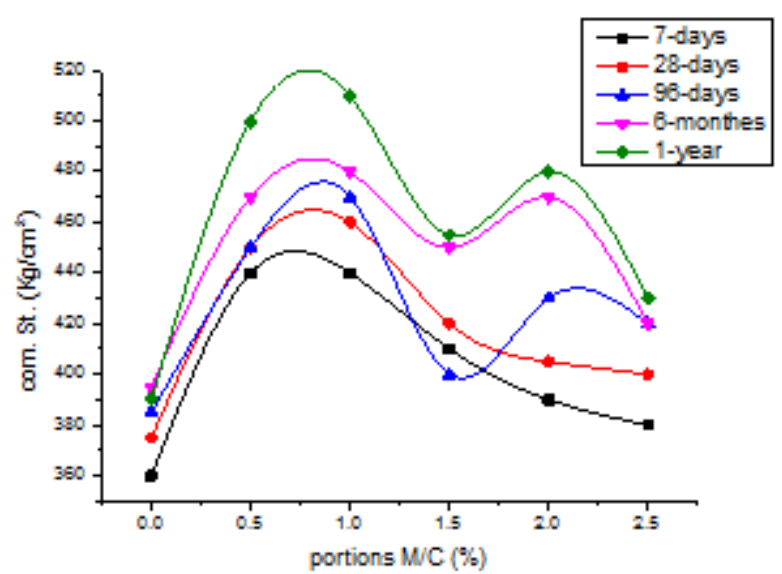

Figure 2: Compressive strength of concrete using BIO with different ages

\subsection{Red iron oxide}

In case of red iron oxides (RIO), the following table will outline the results of slump as well as compressive strength of concrete using (RIO):
Table 5: Slump and compressive strength of concrete using RIO

\begin{tabular}{|c|c|c|c|c|c|c|}
\hline \multirow{2}{*}{$\begin{array}{c}\text { Portion } \\
(\mathrm{M} / \mathrm{C} * \%)\end{array}$} & \multirow{2}{*}{\begin{tabular}{|c} 
Slump \\
$(\mathrm{cm})$
\end{tabular}} & \multicolumn{5}{|c|}{ Compressive strength $\left(\mathrm{kg} / \mathrm{cm}^{2}\right)$} \\
\hline & & 7-days & 28 -days & 96-days & 6-mon. & 1-year \\
\hline 8 & 360 & 375 & 385 & 395 & 390 & 8 \\
\hline 6 & 340 & 350 & 355 & 355 & 360 & 6 \\
\hline 11 & 320 & 335 & 340 & 350 & 350 & 11 \\
\hline 9 & 360 & 380 & 390 & 400 & 400 & 9 \\
\hline 12 & 370 & 385 & 390 & 410 & 420 & 12 \\
\hline 12. & 380 & 395 & 400 & 420 & 440 & 12. \\
\hline
\end{tabular}

RIO make a unique curve which alternating between increasing and decreasing of concrete slump using different portions, this fashion is outline in Fig. 3.

RIO shows relatively small increment in the concrete compressive strength at different ages according to Fig. 4, and this increment in maximum at $2.5 \%$ portion for 1 -year age.

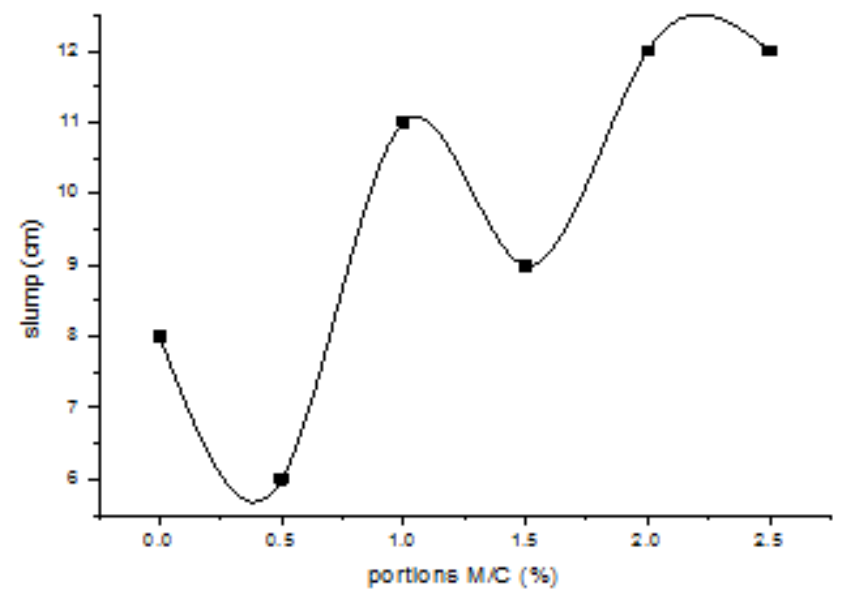

Figure 3: Effect of RIO on the concrete slump

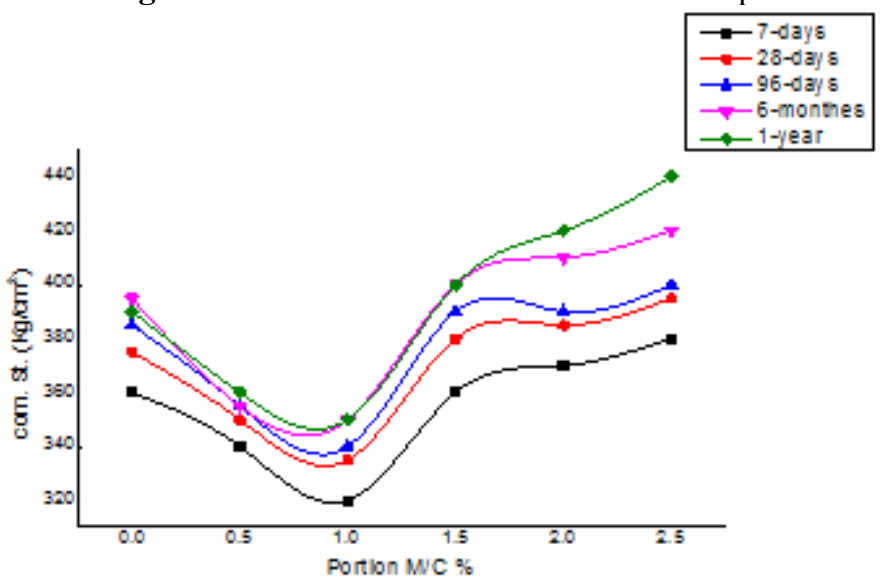

Figure 4: Compressive strength of concrete using RIO with different portions at different ages

In general there are increase in workability as well as increase in compressive strength, but the optimum portion addition shifted from $1 \%$ in case of BIO to be $2.5 \%$ for RIO.

Iron (II, III) oxide (black iron oxide) is a chemical compound with formula $\mathrm{Fe}_{3} \mathrm{O}_{4}$. It contains both $\mathrm{Fe}^{2+}$ and $\mathrm{Fe}^{3+}$ ions and sometimes formulate as $\mathrm{FeO} \cdot \mathrm{Fe}_{2} \mathrm{O}_{3}$. This composition give black iron oxide opportunity to be more reactive than $\mathrm{Fe}_{2} \mathrm{O}_{3}$ (red iron oxide) spatially at media like concrete media. 


\section{International Journal of Science and Research (IJSR) \\ ISSN (Online): 2319-7064 \\ Index Copernicus Value (2013): 6.14 | Impact Factor (2014): 5.611}

As [4], postulate in their work, which pointed in brief in the binging of this article, when surface of iron oxides is covered with $\mathrm{OH}^{-}$ions attached to Fe III ions, these species are called surface functional groups and contribute substantially to the specific adsorption of various anions as inner sphere complexes. Common sorbates are phosphate, silicate, arsenate and sulfate, as well as cations such as heavy metals, or calcium in concrete environment. This adsorption makes the Fe environment act as an efficient sink for these ions thereby restricting the electrostatic interactions.

Surface adsorption operates through $\mathrm{Fe}-\mathrm{OH}$ groups at the surface of Fe-oxides and results from the completion of the ligand shell of surface $\mathrm{Fe}$ atoms. These groups attain negative or positive charge by dissociation or association of protons, depending on the $\mathrm{pH}$ of the surrounding.

$=\mathrm{FeOH} \longrightarrow=\mathrm{FeO}^{-}+\mathrm{H}^{+}$(Dissociation).

$=\mathrm{FeOH}+\mathrm{H}^{+} \longrightarrow=\mathrm{FeOH}_{2}^{+}$(Association).

Furthermore, these complex processes are affected by the presence of other ions, such as $\mathrm{Ca}^{2+}$, both of which serve as an electrolyte, which combine with the hydroxides and oxides of iron to precipitate a variety of $\mathrm{Ca}-\mathrm{Fe}-\mathrm{O}-\mathrm{OH}$ species.[10]

From the above discussion, BIO and RIO act as retarder through inhibiting the ionic reactions occur in the concrete environment at early age, which inflect as increasing in the workability of concrete.

On the other hand, the presence of different oxidation states of iron in $\mathrm{BIO}$ may promote the formation of different phases in the $\mathrm{Ca}-\mathrm{Fe}-\mathrm{O}-\mathrm{OH}$ moiety, which explaine the compressive strength increases. There are some evidences support the above approach as

- By increasing, the percent of BIO, at percentage above 3\% the concrete start to segregate, that mean the binding action of cement started to inhibit.

- The maximum increasing of compressive strength for BIO achieved at $1 \%$ for different ages, but the slump increases by portions of BIO increase, which enhances the assumption of surface adsorption at the surface of Feoxides.

- We tend to make simple experiment to explain the action of $\mathrm{Ca}$-ion in the mixture, by testing the concrete included $5 \%$ of calcium carbonate, and then test this concrete by adding $1 \%$ BIO.

The result of this experiment is out lined in the Fig.5, which indicate that BIO modify the compressive strength of that concrete using calcium carbonate, which may indicate the formation of phases that enhanced the compressive strength. As well as the slump increases from $10 \mathrm{~cm}$ to $13 \mathrm{~cm}$, which may support the surface adsorption assumption.

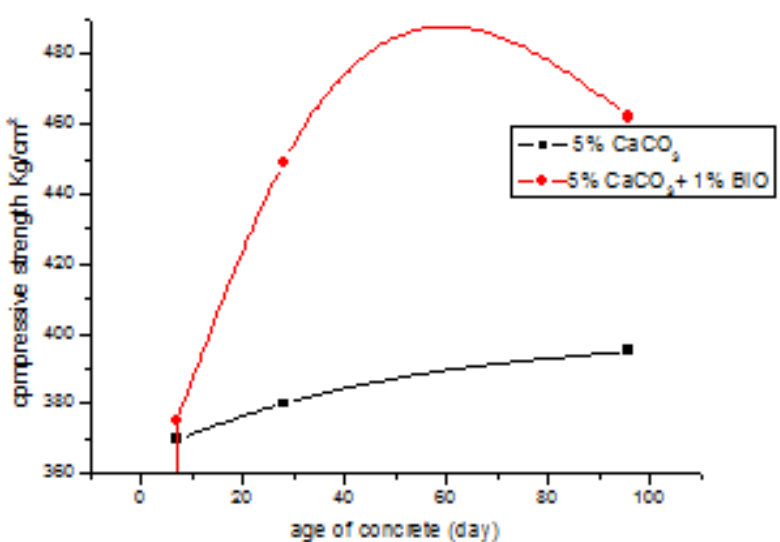

Figure 5: Effect of combination between $\mathrm{BIO}$ and calcium carbonate on concrete

SEM images may give additional clarification of the situation that achieved using iron oxides on concrete as admixtures as follow:

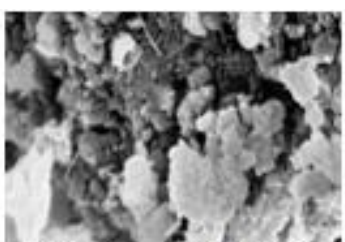

(a). 7 -days; $1 \%$ BIO

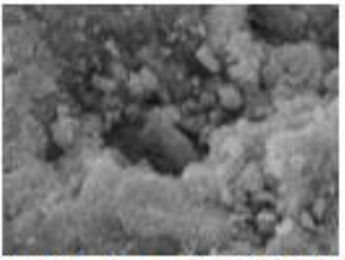

(c). 7 -days; $2.5 \%$ RIO

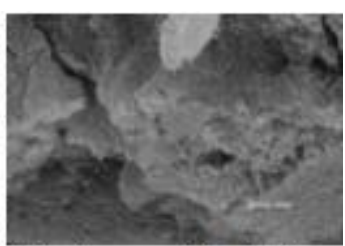

(b). 1-year; $1 \%$ BIO

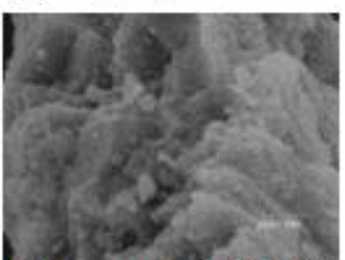

(d). 1 -year; $2.5 \%$ RIO
The above SEM-images are clearly show the formation of $\mathrm{CH}$ phase at 7-days while at 1-year the $\mathrm{C}-\mathrm{S}-\mathrm{H}$ phase is a predominate one, in both cases of RIO and BIO.

The composition of the cementitious material in concrete can have a significant influence on the behavior of all chemical admixtures. Inasmuch as these admixtures affect the early stages of hydration, and are at least partly removed from solution by the early reactions, the cement phases that react most rapidly have a large influence on their action. The early reacting compounds include $\mathrm{C} 3 \mathrm{~A}$ and the alkali and calcium sulfates.[11]

This is clearly appear through the following Fig.6, of XRDpattern of $\mathrm{BIO}$ as well as RIO, in the comparison with M0 (blank or control), and sand that used throughout this study.

The hydration of the cement components results are the conversion of $\mathrm{C}_{3} \mathrm{~S}$ and $\beta-\mathrm{C}_{2} \mathrm{~S}$ into the hydration products, calcium silicate hydrate $(\mathrm{CSH})$ and calcium hydroxide $(\mathrm{CH})$ as shown in above Fig.6. Accordingly, the intensity of the characteristic peaks of the reactants such as alite and belite phases decreases with increasing the hydration age. 


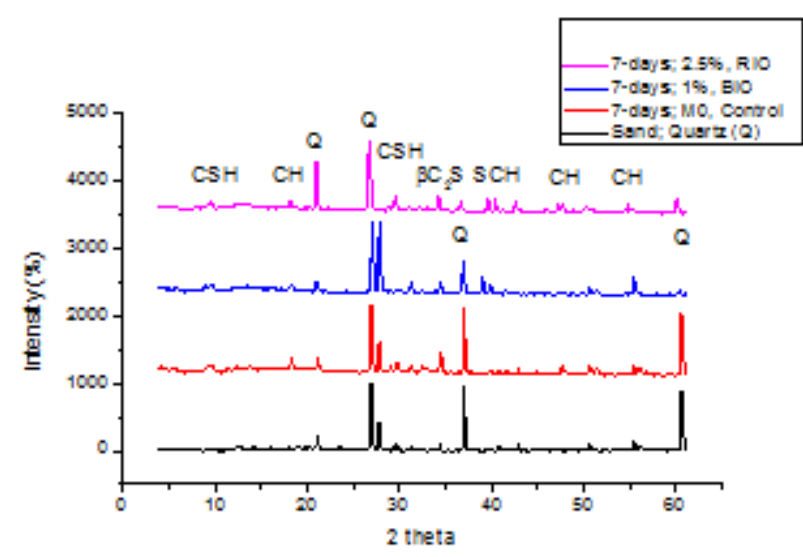

Figure 6: XRD-patterns of $\mathrm{BIO}$ and RIO, in the comparison with M0 (blank or control), and sand

\section{Conclusion}

From the obtained results it can be concluded that:

1)For $\mathrm{BIO} 1 \%$ is the optimum percent, it increase the slump $6.25 \%$ and the compressive strength by $22-30 \%$. So it can be used as mineral admixture.

2)For RIO $2.5 \%$ is the optimum percent, it increase the slump $50 \%$ and the compressive strength by $5-3012 \%$. So it can be used as retarder.

\section{References}

[1] PCA, Kosmatka, Steven H.; Kerkhoff, Beatrix; and Panarese, William C.; Design and Control of Concrete Mixtures, EB001, 14th edition, Portland Cement Association, Skokie, Illinois, USA, 2012.

[2] Shekari, A. H., \& Razzaghi, M. S.; Influence of Nano Particles on Durability and Mechanical Properties of High Performance Concrete. Procedia Engineering, pp. 3036-3041, 2011.

[3] Lee, H. S.; Lee , J. Y.; \& Yu ; M. Y. Influence of iron oxide pigments on the properties of concrete interlocking blocks. Cement and Concrete Research, pp. 1889-1896, 2003.

[4] Cornell, R.M., and Schwertmann, U., "The Iron Oxides", 2nd edn.Weinheim: Wiley-VCH, pp. 664, 2003.

[5] ACI Committee 211, "Standard Practice for Selecting Proportions for Normal", Heavyweight and Mass Concrete, ACI 211.1-91, American Concrete Institute, Farmington Hills, Michigan, 1991.

[6] ASTM C 192, 'Standard Practice for Making and Curing Concrete Test Specimens in the Laboratory", 2000.

[7] ASTM C 143, "Standard Test Method for Slump of Hydraulic Cement Concrete", 2000.

[8] ASTM C 39, "Standard Test Method for Compressive Strength of Cylindrical Concrete Specimens", 2001.

[9] BS 1881: Part 127, "Testing concrete. Method of verifying the performance of concrete using the comparative cube test", 1990.

[10] Gräfen, H.; Horn, E. M.; Schlecker, H.; Schindler, H. "Corrosion". Ullmann's Encyclopedia of Industrial Chemistry. Wiley-VCH, 2000.

[11] ACI Committee 225, "Guide to the selection and use of hydraulic cements", ACI 225R-99, American Concrete Institute, Farmington Hills, Michigan, 1999.

\section{Author Profile}

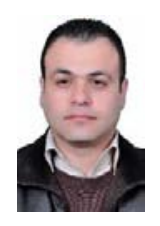

Muhammad Alasqalani received the B.S. and M.S. degrees in industrial and pure chemistry respectively from Al-Azhar university in 2001 and 2007. During 2008-2014, he stayed in University Collage for Applied Sciences (UCAS), as lecturer for different topics of applied and pure chemistry since September 2014 he conducted with Israa University-Gaza as head of scientific research department. 